\title{
PENGELOLAAN SUMBER DAYA IKAN DI DANAU LIMBOTO, GORONTALO
}

\author{
Krismono $^{1)}$ dan Endi Setiadi Kartamihardja ${ }^{2)}$ \\ 1)Peneliti pada Balai Riset Pemulihan Sumber Daya Ikan, Jatiluhur-Purwakarta \\ 2) Peneliti pada Pusat Penelitian Pengelolaan Perikanan dan Konservasi Sumber Daya Ikan, Ancol-Jakarta \\ Teregistrasi I tanggal: 16 Maret 2009; Diterima setelah perbaikan tanggal: 20 April 2010; \\ Disetujui terbit tanggal: 30 April 2010
}

\begin{abstract}
ABSTRAK
Danau Limboto termasuk danau tipe rawa terletak di Provinsi Gorontalo dengan luas 2.900 ha dan kedalaman antara 1-5 m. Sumber air berasal dari 20 sungai dan empat sungai di antaranya merupakan sungai besar, yaitu Sungai Bionga, Sungai Molalahu, Sungai Alo-pahu, dan Sungai Meluopo. Air Danau Limboto dikeluarkan melalui Sungai Topadu yang bermuara di Teluk Tomini dengan jarak sekitar $10 \mathrm{~km}$. Masalah Danau Limboto adalah eutrofikasi dan sedimentasi, eutrofikasi ditandai dengan pertumbuhan gulma air eceng gondok yang berkembang terus dari tahun ke tahun. Pada tahun 1994 tumbuhan air menutupi sekitar 35\%, tahun 2004 sampai 40\% dan tahun 2008 sekitar 40-60\% luas permukaan air. Struktur komunitas ikan di Danau Limboto didominansi oleh ikan karnívora dan omnivora sehingga hanya sebagian kecil yang memanfaatkan eceng gondok sebagai makanannya. Sekitar 1.500 kepala keluarga hidup di selingkar Danau Limboto dengan mata pencaharian pembudidaya ikan dan nelayan. Beberapa alat tangkap yang merusak sumber daya ikan antara lain dudayaho, strom, dan bibilo. Untuk menjaga kelestarian sumber daya ikan perlu dilakukan langkah-langkah pengelolaan secara berkelanjutan meliputi rehabilitasi habitat danau melalui pengendalian eceng gondok, penentuan tata ruang perairan danau, revitalisasi Peraturan Daerah Kabupaten Gorontalo Nomor 67 Tahun 2000 mengenai pelarangan penggunaan alat tangkap yang merusak sumber daya ikan, revitalisasi kelembagaan nelayan, dan pembudidaya ikan.
\end{abstract}

KATA KUNCl: pengelolaan, sumber daya ikan, perikanan, Danau Limboto

ABSTRACT: $\quad \begin{aligned} & \text { Management of fisheries resources in Limboto Lake By: } \\ & \text { Krismono and Endi Setiadi Kartamihardja }\end{aligned}$

Lake Limboto is classified as swamp lake types located in the Province of Gorontalo, has a water surface area of 2,900 ha and water depth range between 1-5 $\mathrm{m}$. The source of water comes from 20 rivers; among others are four major rivers, namely Bionga, Molalahu, Alo-Pahu, and Meluopo Rivers. The outlet of the lake waters is Topadu River which empties into Tomini Bay about $15 \mathrm{~km}$ distance from the lake. The main problem of the lake is eutrofication and sedimentation which the eutrofication indicated by the nuisance growth of aquatic weeds especially water hyacinth. In 1994, the water hyacinth covered the water surface area of 35\%, in 2004 to be $40 \%$ and in 2008 approximately covered 40 $60 \%$ of the total water surface area of the lake. Structure of fish communities is dominated by carnivorous and omnivorous fish so that only a small part water hyacinth utilized as fish feed. Lake Limboto support around 1,500 families live surrounding of the lake that their livelihoods as fish farmers and fishermen. Some 


\begin{abstract}
fishing gears such as scope net of fine mesh size, electric fishing and aquatic plant fish aggregating device has destructed the fish resources. To maintain the sustainability of fish resources some management measures i.e. habitat rehabilitation of the lake through water hyacinth control, zoning of the lake, revitalization of Gorontalo District Act Nomor 67 year 2000 about prohibition on the use of destructive fishing gears; and development of fisheries co-management should be done.
\end{abstract}

\title{
KEYWORDS: $\quad$ management, fish resources, fisheries, Limboto Lake
}

\section{PENDAHULUAN}

Danau Limboto termasuk danau tipe rawa terletak di Kabupaten dan Kota Gorontalo, Provinsi Gorontalo pada posisi 0³4'57,54"0³5'06,78" LU dan 122 56'41,45"$123^{\circ} 00^{\prime} 43,94^{\prime \prime}$ BT. Danau Limboto mempunyai luas permukaan air 2.900 ha dengan kisaran kedalaman antara 1-5 m dan rata-rata kedalaman 2,0 m. Sumber air Danau Limboto berasal dari 20 sungai dan empat sungai di antaranya merupakan sungai besar, yaitu Sungai Bionga, Sungai Molalahu, Sungai Alo-Pahu, dan Sungai Meluopo. Sungai Topadu merupakan satusatunya saluran pengeluaran air danau yang bermuara di laut Teluk Tomini dengan panjang sungai sekitar $15 \mathrm{~km}$ (Ismail, 2006).

Pada tahun 1994, pertumbuhan gulma air eceng gondok di Danau Limboto sudah menutupi permukaan air sekitar 35\% (Sarnita, 1994), penutupannya meningkat mencapai 40\% pada tahun 2004 (Hulinggi, 2005), dan pada tahun 2008 sudah mencapai sekitar 40-60\% luas permukaan danau (Krismono et al., 2007). Penutupan gulma air eceng gondok mengakibatkan penyempitan luas perairan, penurunan mutu air dan mengganggu populasi ikan. Evaporasi pada permukaan air yang tertutup oleh gulma air eceng gondok mempunyai kecepatan tiga kali lebih cepat dibandingkan dengan permukaan perairan yang terbuka (Penfaund \& Early, 1948). Tumbuhan eceng gondok di perairan danau selain merugikan namun dalam jumlah tertentu mempunyai fungsi yang menguntungkan karena dapat berfungsi sebagai tempat pemijahan, mencari makan, berlindung dari predator untuk jenis-jenis ikan asli dan introduksi, serta jenis ikan katadromus yang hidup di danau dan memijah di laut.

Sedimentasi dan eutrofikasi di Danau Limboto disebabkan juga oleh kegiatan masyarakat sekitar dalam pemanfaatan danau seperti pembuatan bibilo untuk menangkap ikan dan kegiatan budi daya ikan dalam keramba jaring apung (Warsa et al., 2008). Berdasarkan atas kriteria dari Kementerian Lingkungan Hidup, Danau Limboto merupakan salah satu danau di Indonesia yang sudah termasuk dalam kriteria danau kritis akibat sedimentasi dan eutrofikasi (Kementerian Lingkungan Hidup, 2006).

Bila sedimentasi dan eutrofikasi tidak dicegah, maka fungsi Danau Limboto sebagai cadangan air dan penahan banjir serta fungsi-fungsi ekosistem lain akan hilang. Kehilangan fungsi danau berakibat pada hilangnya sumber daya ikan danau dan mata pencaharian nelayan. Untuk mempertahankan ekosistem perairan dan sumber daya ikan di Danau Limboto diperlukan langkah-langkah pengelolaan sumber daya ikan dan perikanan yang berkelanjutan.

Tulisan ini bertujuan untuk membahas kondisi perairan dan sumber daya ikan 
serta implikasi pengelolaannya bagi kelestarian sumber daya ikan dan keberlanjutan usaha perikanan di Danau Limboto.

\section{KARAKTERISTIK SUMBER DAYA PERAIRAN DAN IKAN}

\section{Morfometri dan Hidrologi Danau}

Danau Limboto berdasarkan atas klasifikasi Ramsar mengenai lahan basah (wetland) merupakan danau tipe rawa (Badan Perencanaan Pembangunan Nasional, 2003), sedangkan berdasarkan atas proses terbentuknya Danau Limboto merupakan danau tipe genangan (Whitten et al., 1987). Menurut klasifikasi Schmidt Ferguson, Danau Limboto termasuk dalam tipe iklim $C$ dengan kisaran suhu antara $22,2-33,3^{\circ} \mathrm{C}$. Musim hujan terjadi antara bulan Desember sampai April dengan kisaran curah hujan berkisar antara 1.320 sampai $1.680 \mathrm{~mm} /$ tahun (Ismail, 2006). Tinggi muka air danau tertinggi terjadi antara bulan April sampai Mei dan terendah pada bulan September sampai Desember (Anonimus, 2006). Air masuk danau mulai bulan September sampai Desember dan keluar danau mulai bulan Mei sampai Agustus.

Pada tahun 1932, Danau Limboto mempunyai luas permukaan air 7.000 ha dengan kedalaman $14 \mathrm{~m}$, namun pada tahun 1999, luasnya menjadi 3.000 ha dengan kedalaman berkisar antara 2-4 m. Pengurangan luas permukaan Danau Limboto antara lain disebabkan oleh laju sedimentasi yang cukup tinggi, yaitu 38,80 cm/tahun (Ismail, 2006).

Danau Limboto sebagai ekosistem lahan basah secara ekologi merupakan ekosistem yang penting untuk konservasi keragaman jenis dan keanekaragaman genetik di alam. Lahan basah di alam, diketahui mempunyai keanekaragaman hayati yang tinggi, penting dalam proses penahan laju sedimentasi, erosi dan pengendalian banjir, serta pengaturan kualitas air dengan mereduksi bahan-bahan pencemar sehingga lahan basah berfungsi juga sebagai cadangan air dan stabilitas iklim secara global. Lahan basah bagi masyarakat sekitar dapat menghasilkan produksi dari sumber daya perikanan, pertanian, dan kehutanan. Akhir-akhir ini penyempitan lahan basah telah terjadi di berbagai daerah yang disertai kerusakan fisik dan biologis ekosistemnya (Badan Perencanaan Pembangunan Nasional, 2003).

Lahan basah merupakan habitat yang penting bagi organisme perairan dalam sebagian daur hidupnya yang menggunakan ekosistem lahan basah sebagai tempat hidup seperti ikan sidat (Anguilla marmorata) yang beruaya ke laut dalam pemijahannya. Danau Limboto sebagai lahan basah juga berfungsi sebagai tempat untuk berkembang biak, berlindung, mencari makan, pemijahan, serta sebagai tempat untuk kehidupan ikan.

\section{Tingkat Kesuburan Perairan}

Danau Limboto termasuk perairan yang subur (eutrofik) dengan kandungan ortofosfat (P-PO4) rata-rata $1.428 \mathrm{mg} / \mathrm{L}$ (Krismono et al., 2009). Perairan danau yang relatif dangkal dengan kandungan nutrien yang tinggi memacu pertumbuhan makrofita.

Potensi produksi ikan di suatu perairan danau dapat diukur dari kandungan klorofila yaitu pigmen hijau yang terdapat di dalam tumbuhan yang dapat mengubah cahaya matahari menjadi energi kimia dalam proses fotosintesis. Kandungan klorofil-a di Danau Limboto berkisar antara 6.338-38.803 mg/ $\mathrm{m}^{3}$ dengan rata-rata $16.886 \mathrm{mg} / \mathrm{m}^{3}$. Berdasarkan atas nilai klorofil-a tersebut, 
potensi produksi ikan Danau Limboto ditaksir antara 151.678-752.479 kg/ha/tahun dengan rata-rata $355.013 \mathrm{~kg} / \mathrm{ha} / \mathrm{tahun}$.

\section{Gulma Air Eceng Gondok (Eicchornia crassipes)}

Menurut Soerjani et al. (1976); Pancho dalam Soerjani (1982) eceng gondok tercatat di nomor urutan pertama jenis gulma yang sangat penting baik di Dunia, Asia Tenggara, dan khususnya di Indonesia. Eicchhornia crassipes (Mart.) Solms adalah sinonim dari Eicchhornia spiciosa Kunth, tumbuhan ini berasal dari Brazilia dan tersebar ke beberapa negara karena tanaman ini memiliki bunga yang indah (Soerjani, 1982).

Secara taksonomis, eceng gondok (Eicchhornia crassipes Solms), termasuk dalam klasifikasi sebagai berikut (Soerjani, 1982):

$\begin{array}{ll}\text { Divisi } & \text { : Spermatophyta } \\ \text { Sub Divisi } & \text { : Angiospermae } \\ \text { Kelas } & : \text { Monocotyledoneae } \\ \text { Bangsa } & \text { : Bromeliales } \\ \text { Suku } & \text { : Pontederiaceae } \\ \text { Marga } & : \text { Eicchhornia } \\ \text { Jenis } & : \text { Eicchhornia } \\ & \text { crassipes Solms } \\ \text { Nama umum/ : Eceng gondok } \\ \text { dagang } & \text { (Waterhyacinth) }\end{array}$

Gulma air di Indonesia diketahui pada tahun 1928-1929 melalui Deutschen Limnologischen Sunda Expedition dan pertama kali dicatat 80 jenis gulma terdapat di perairan Indonesia (Van Steenis \& Ruttner, 1933). Tahun 1949 tercatat 24 jenis gulma terdapat di Rawa Pening (Vass \& Schuurman, 1949), tahun 1956 di Rawa Aopa Sulawesi Tenggara diadakan inventarisasi gulma oleh Vass (1956). Menurut Soerjani (1981) pada tahun 19771978 di Danau Singkarak, ditemukan jenis gulma air yang dominan seperti Potamogeton sp. dan eceng gondok. Pada saat bersamaan di Danau Maninjau tercatat adanya eceng gondok, Hydrilla dan Najas. Pada tahun 1978-1979 di Danau Kerinci ditemukan eceng gondok yang menutup perairan sekitar 500-600 ha.

Perkembangan jenis-jenis tumbuhan air di Danau Limboto tertera pada Tabel 1 dan 2 (Anonimus, 1991; Lamangantjo, 1991; Hulinggi, 2005; Krismono et al., 2007). Eceng gondok merupakan tumbuhan air yang paling dominan serta sudah mengganggu permukaan air danau sehingga sudah termasuk gulma air. Hasil penelitian Lamangantjo (1991) menunjukan bahwa eceng gondok yang dijadikan bibilo mempengaruhi penurunan suhu dan $\mathrm{pH}$, sehingga mengganggu kehidupan ikan di perairan Danau Limboto karena suhu dan pH mempengaruhi aktivitas pemijahan dan pertumbuhannya.

Komposisi tumbuhan air di Danau Limboto didominansi oleh eceng gondok 85\%, ganggang (Hydrilla sp.), kangkung air, rumput, tumbili masing-masing hanya 2,5\%, dan teratai, serta kiambang masingmasing 0,5\% (Krismono et al., 2007). Peran eceng gondok di Danau Limboto sangat besar dilihat dari komposisi tumbuhan air tersebut di atas. Peran eceng gondok tersebut dapat berdampak negatif maupun positif terhadap ekosistem perairan.

Gulma air selain berdampak negatif juga mempunyai fungsi positif bagi perikanan. Beberapa hasil penelitian Petr (2000); Pokorny \& Kvet (2004); Pipalova (2006); Krismono et al. (2007) mengatakan bahwa makrofita merupakan komponen yang penting dari ekosistem, sebagai penghasil oksigen untuk fotosintesis, habitat pemijahan ikan, asuhan ikan, menempelnya pakan alami dari hewan, dan konsentrasi 
nutrien. Secara umum, pengaruh makrofita bagian dari rantai stabilitas perairan. pada ekosistem danau adalah merupakan

Tabel 1. Jenis-jenis tumbuhan air di Danau Limboto, tahun 2004 dan 2007

Table 1. The types of aquatic plants in Lake Limboto, in 2004 and 2007

Sumber/Sources: Hulinggi (2005); Krismono et al. (2007)

Tabel 2. Komposisi tumbuhan air di Danau Limboto, tahun 2006

Table 2. The composition of aquatic plants in Lake Limboto, 2006

\begin{tabular}{|c|c|c|c|c|c|}
\hline $\begin{array}{l}\text { Nama lokall } \\
\text { Local name }\end{array}$ & $\begin{array}{c}\text { Nama ilmiah/ } \\
\text { Scientific name }\end{array}$ & $\begin{array}{l}\text { Persen } \\
\text { Percent }\end{array}$ & $\begin{array}{l}\text { se di perairanl } \\
\text { e in waters (\%) }\end{array}$ & $\begin{array}{l}\text { Daunl } \\
\text { Leaf }\end{array}$ & \\
\hline Eceng gondok & Eichhornia crassipes & & 85 & Mengapung & \\
\hline Hydrilla & Hydrilla verticillata & & 2,5 & Tenggelam & \\
\hline kangkung air & Ipomea aquatica & & 2,5 & Mengapung & \\
\hline $\begin{array}{l}\text { Rumput } \\
\text { Tumbili }\end{array}$ & $\begin{array}{l}\text { Panicum repens } \\
\text { Pistia stratiotes }\end{array}$ & $\begin{array}{l}\text { Nama De } \\
\text { Region }\end{array}$ & rahis & Mёabapเ2094 & \\
\hline Iumbill & $\begin{array}{l}\text { PIstla stratiotes } \\
\text { Alternanthera philoxiroides }\end{array}$ & Eceng gondok & Eicchor & $\begin{array}{l}\text { Mengapung } \\
\text { ia crassipes }\end{array}$ & Eicchornia cra \\
\hline Rumput & Scirpus mucronatus & Hydrilla & Hydrilla & $\begin{array}{l}\text { verticlllatd } \\
\text { vengapung }\end{array}$ & \\
\hline Teratai & Nelumbium sp. & Tumbili & Pistia s & $\begin{array}{l}\text { Mengapung } \\
\text { ratiotes }\end{array}$ & $\begin{array}{l}\text { Ipomea aquat } \\
\text { Pistia stratiote }\end{array}$ \\
\hline Kiambang & Azolla pinata & Rumput & Seirpus & $\begin{array}{l}\text { Mengapung } \\
\text { mutrotatts }\end{array}$ & Scirpus mucre \\
\hline \multicolumn{2}{|c|}{ Sumber/Sources: Krismono et al. (2007) } & $\begin{array}{l}\text { Teratai } \\
\text { Kiambang }\end{array}$ & Nymph & e odorata & Azollambium si \\
\hline
\end{tabular}

sebagai pembersih limbah rumah tangga (Djaenudin, 2006), eceng gondok juga dapat membersihkan waduk dan danau dari cemaran pestisida dan logam berat (Hasim, 2007; Petr, 2000; Marson, 2006). Peran akar makrofit (eceng gondok) menentukan ekosistem permukaan perairan (dilihat berdasarkan atas aspek kualitas air, plankton, ikan). Eceng gondok dapat digunakan sebagai pakan ikan dan pupuk untuk sawah (Rahmi, 1999). terdiri atas bagian akar $41,4 \%$, petiole $50,6 \%$, dan daun $8 \%$, sedangkan kandungan air eceng gondok $90 \%$ dengan pengeringan menggunakan oven pada suhu $105^{\circ} \mathrm{C}$ (Tabel 3). Menurut Wetzel (2001) bagian akar sekitar $20-50 \%$ total biomassa. Secara keseluruhan, kandungan protein eceng gondok $11,4 \%$ sedangkan menurut Wahyono et al. (2006) kandungan protein kasar dari eceng gondok $11,2 \%$. 
J. Kebijak. Perikan. Ind. Vol.2 No. 1 Mei 2010: 27 - 41

Tabel 3. Komposisi bobot kering (1 kg) eceng gondok dari Danau Limbeto Table 3. Composition of dry weight $(1 \mathrm{~kg})$ of water hyacinth from Lake Limbote

\begin{tabular}{lccc}
\hline $\begin{array}{c}\text { Bagian tanaman I } \\
\text { Plant parts }\end{array}$ & $\begin{array}{c}\text { Persentase/ } \\
\text { Percentage (\%) }\end{array}$ & $\begin{array}{c}\text { Bagian tanaman/ } \\
\text { Plant parts }\end{array}$ & $\begin{array}{c}\text { Persentasef } \\
\text { Percentage (\%) }\end{array}$ \\
\hline Akar & 41,4 & Daun & 8,0 \\
Petiole & 50,6 & & \\
Sumber/Sources: Hasil analisis laboratorium Loka Riset Pemacuan Stok Ikan Jatiluhur (2007)
\end{tabular}

Beberapa hasil analisis bahan organik pada eceng gondok tertera pada Tabel 4. Menurut Hakim et al., 1986 dalam Haryatun (2008) rasio $\mathrm{C} / \mathrm{N}$ eceng gondok termasuk rendah, dekomposisi cepat, maka eceng gondok dapat berfungsi sebagai sumber hara dan bahan organik. Hasil penelitian
Karki \& Dixit (1984) dalam Haryati (2006) rasio $\mathrm{C} / \mathrm{N}$ eceng gondok 25 lebih kecil dibanding $\mathrm{C} / \mathrm{N}$ jerami padi 70 dan jagung 60 , tetapi lebih besar dibanding kotoran ayam 10 , kotoran kambing 12 serta kotoran manusia dan bebek delapan.

Tabel 4. Kandungan bahan organik dalam eceng gondok Table 4. Organic matter content in water hyacinth

\begin{tabular}{lccc}
\hline $\begin{array}{c}\text { Bahan organikJ } \\
\text { Organic matter }\end{array}$ & $\begin{array}{c}\text { Persentasel } \\
\text { Percentage }\end{array}$ & $\begin{array}{c}\text { Persentasel } \\
\text { Percentage }\end{array}$ & $\begin{array}{c}\text { Persentase/ } \\
\text { Percentage }\end{array}$ \\
\hline N-organik & 2,32 & 1,68 & 0,28 \\
P-organik & 0,24 & 0,27 & 0,001 \\
K-organik & 1,95 & 14,29 & 0,016 \\
C-organik & 46,21 & 37,65 & 21,23 \\
C/N rasio & 19,92 & 22,40 & - \\
\hline
\end{tabular}

Sumber/Sources: Haryatun (2008); Rahmi (1999)

Eceng gondok merupakan bahan yang potensial untuk bahan organik. Nutrien eceng gondok yang berbunga dan tidak berbunga mempengaruhi ikan herbivora yang ada di perairan sekitarnya (Center et al., 2005). Hasil penelitian Nurminem (2003) memperlihatkan bahwa adanya makrofita di perairan danau merefleksikan kualitas air antara lain total $\mathrm{N}$, total $\mathrm{P}$, kecerahan, turbiditas, kedalaman, dan dasar perairan dari danau tersebut. Perubahan kualitas air tersebut di atas yang disebabkan oleh penambahan nutrien akan mempercepat proses eutrofikasi.

\section{Struktur Komunitas Ikan}

Komunitas ikan di Danau Limboto terdiri atas jenis-jenis ikan asli dan ikan introduksi. Jenis-jenis ikan asli adalah ikan betok (Anabas testudineus), payangka (Ophiocara porocephala), dan manggabae (Glossogobius giuris), jenis ikan introduksi antara lain ikan gabus (Channa striata), nila (Oreochromis niloticus), mujair (Oreochromis mossambicus), tawes (Barbonymus gonionotus), dan sepat (Trichogaster pectoralis), sedangkan jenis ikan peruaya adalah ikan sidat (Anguilla marmorata) dan belanak (Mugil sp.). Menurut klasifikasi Odum (1998) komunitas 
ikan di Danau Limboto mempunyai keanekaragaman yang rendah.

Pada tahun 2006 produksi ikan hasil tangkapan nelayan di Danau Limboto
639,64 ton dengan komposisi persentase hasil tangkapan terbesar adalah ikan nila (24\%) dan mujair $(22,8 \%)$ seperti tertera pada Tabel 5 (Krismono et al., 2007).

Tabel 6. Status trofik komunitas ikan di Danau Limboto

Table 6. Trophic status of fish communities in Lake Limboto

\begin{tabular}{|c|c|c|c|}
\hline \multirow{2}{*}{$\begin{array}{l}\text { Tingkat trofikl } \\
\text { Trophic level }\end{array}$} & \multirow{2}{*}{$\begin{array}{l}\text { Jenis ikan/ } \\
\text { Type of fish }\end{array}$} & \multicolumn{2}{|c|}{ Jenis makanan/Type of food } \\
\hline & & Utama/Main & $\begin{array}{l}\text { Pelengkapl } \\
\text { Complement }\end{array}$ \\
\hline Herbivora & $\begin{array}{l}\text { Tawes (Barbonymus gonionotus) } \\
\text { Saribu (Trichogaster pectoralis) }\end{array}$ & Serasah tumbuhan & $\begin{array}{l}\text { Fitoplankton } \\
\text { Detritus }\end{array}$ \\
\hline Omnivora & $\begin{array}{l}\text { Nila (Oreochromis niloticus) } \\
\text { Mujair (Oreochromis mossambicus) } \\
\text { Dumbaya (Anabas testudineus) }\end{array}$ & $\begin{array}{l}\text { Fitoplankton } \\
\text { Larva serangga, } \\
\text { Serasah tumbuhan }\end{array}$ & Detritus, serangga \\
\hline Karnivora & $\begin{array}{l}\text { Manggabae (Glossogobius giuris) } \\
\text { Payangga (Ophiocara porocrphala) } \\
\text { Gabus (Channa striata) }\end{array}$ & $\begin{array}{l}\text { Ikan, udang, } \\
\text { serangga }\end{array}$ & $\begin{array}{l}\text { Serangga, siput, } \\
\text { kerang, serasah }\end{array}$ \\
\hline
\end{tabular}

Sumber/Sources: Krismono et al. (2007)

Komunitas ikan didominansi oleh jenis ikan omnivora $46 \%$, selanjutnya karnivora $31 \%$, dan herbivora $21 \%$, sedangkan tingkat trofiknya tertera pada Tabel 6 . Untuk ikan karnivora khususnya manggabae dan payangga walaupun produksi dalam biomassa sekitar $22,5 \%$, tetapi dalam jumlah individu dapat lebih dari 50\% karena ukurannya yang kecil hanya sekitar 5-50 g, padahal menurut Eccles (1992) panjang maksimum ikan manggabae dapat mencapai $50 \mathrm{~cm}$.

\section{STATUS PERIKANAN}

Kegiatan perikanan yang berkembang $\mathrm{di}$ Danau Limboto adalah perikanan tangkap dan budi daya. Perikanan tangkap sudah berkembang sejak lama sedangkan perikanan budi daya baru berkembang setelah tahun 1990-an.

\section{Perikanan Tangkap}

Jenis alat tangkap yang digunakan oleh nelayan dalam kegiatan penangkapan ikan sangat beragam seperti tertera pada Tabel 7. Penangkapan ikan di Danau Limboto dilakukan hampir setiap waktu dengan tipe alat tangkap dan nelayan yang berbeda secara bergantian.

Bibilo adalah alat tangkap ikan dengan memanfaatkan tumbuhan air yang mengelompok menyerupai pulau terapung. Kelompok tumbuhan air tersebut berukuran luas $20 \times 30 \mathrm{~m}^{2}$ sampai yang berukuran besar yaitu $20 \times 50 \mathrm{~m}^{2}$. Penangkapan ikan dilakukan dengan cara mengurung kelompok tumbuhan air dengan jaring polyethilene ukuran 1 inci. Penangkapan ikan tersebut dilakukan setiap 3-6 bulan sekali. Ikan yang terkurung ditangkap menggunakan seser. Alat tangkap tiopo, olate, dan amelo pada dasarnya sama dengan bibilo, yang membedakan adalah ukurannya semakin mengecil.

Saat ini jumlah nelayan yang menggunakan alat tangkap jenis bibilo mencapai 785 RTP (54,6\%). Apabila untuk setiap unit bibilo yang dipasang, 
memerlukan perairan seluas $100-600 \mathrm{~m}^{2}$ atau rata-rata $300 \mathrm{~m}^{2}$ dan setiap RTP memiliki 3 unit, maka luas permukaan air

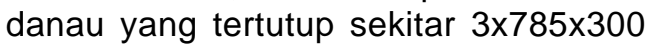
$\mathrm{m}^{2}=720$ ha atau sekitar $25 \%$ dari luas permukaan perairan danau. Selain alat tangkap bibilo yang sangat mempengaruhi keberlanjutan sumber daya ikan adalah penangkapan ikan yang menggunakan seser dengan strom (electro fishing) dan dudayaho, yaitu alat tangkap serok atau scope net dengan mata jaring lebih kecil dari 1 inci.

Dudayaho adalah alat tangkap ikan yang terbuat dari waring berbentuk kantong dengan panjang $5 \mathrm{~m}$ dan lebar 2-3 $\mathrm{m}$, sebagai penyangga digunakan bambu dengan panjang kurang lebih 2 m (Gambar 1). Alat tangkap tersebut dioperasikan nelayan menggunakan perahu bermesin dan penangkapan ikan dilakukan setiap hari.

Tabel 7. Jumlah RTP nelayan berdasarkan atas jenis alat tangkap yang dimiliki di Danau Limboto

Table 7. Number of RTP based on the type of fishing gear owned by the Lake Limboto

\begin{tabular}{lcc}
\hline \multicolumn{1}{c}{$\begin{array}{c}\text { Jenis alat tangkapl } \\
\text { Types of fishing gear }\end{array}$} & $\begin{array}{c}\text { Persentase } \\
\text { jumlah RTPI } \\
\text { Percentage } \\
\text { Number of RTP } \\
\text { (\%) }\end{array}$ & $\begin{array}{c}\text { Rata rata- } \\
\text { kepemilikan/ } \\
\text { Percentage number } \\
\text { of RTP } \\
\text { (unit/RTP) }\end{array}$ \\
\hline 1. Bibilo (Fish aggregating device using aquatic plant) & 54,59 & 3 \\
2. Tiopo (bambo trap) & 6,88 & 1 \\
3. Amelo (shrimp scope net) & 13,75 & 1 \\
4. Olate (encircling bammbo trap) & 13,75 & 1 \\
5. Lainnya: & 11,62 & 3 \\
1.Pancing Rawai (long lines) & & 3 \\
1.Pajala (Gillnet) & & 1 \\
2.Jala (castnet) & & 1 \\
3.Sero (trap) & & 1 \\
4.Sodo (scope net) & & 200 \\
5.Bunggo/bubu (trap) & & 3 \\
\hline
\end{tabular}

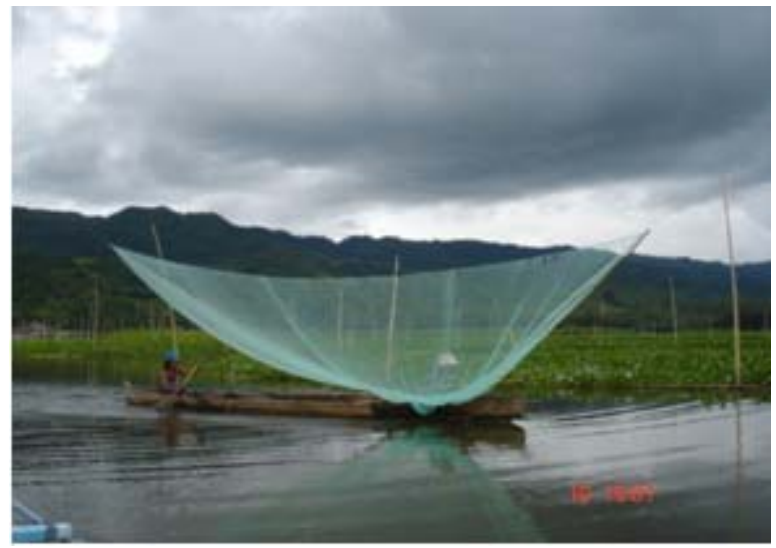

Gambar 1. Alat tangkap Dudayaho.

Figure $1 . \quad$ Dudayaho gear. 
Pada umumnya, hasil tangkapan nelayan diambil oleh pedagang pengumpul, sebagian kecil oleh nelayan dijual ke konsumen dengan cara menjajakan secara langsung. Jumlah hasil tangkapan berfluktuasi sesuai musim, berkisar antara 2-12 kg/RTP/hari. Hasil tangkapan ikan tertinggi $12 \mathrm{~kg} / \mathrm{RTP} /$ hari dicapai saat musim ikan. Jumlah nelayan total 1.454 RTP sedangkan yang aktif hanya 1.118 RTP (76,9\%). Jenis ikan payangga dan manggabai merupakan jenis ikan dengan jumlah produksi cukup tinggi, di mana puncak produksi tertinggi dicapai pada bulan Januari sampai Juni dengan total tangkapan $508 \mathrm{~kg}$ ikan/ha/tahun, pada luas perairan 2.900 ha. Ikan manggabai dan belut merupakan jenis ikan yang bernilai ekonomis tinggi, harga ikan manggabai mencapai Rp.10.000/ekor (ukuran 200-250 g/ekor) atau sekitar Rp.40.000/kg, sedangkan harga ikan belut mencapai Rp.50.000/kg.

\section{Perikanan Budi Daya}

Budi daya ikan dilakukan dengan sistem keramba jaring apung dan keramba tancap. Saat ini ada sekitar 379 RTP pembudidaya, dengan jumlah petak yang diusahakan berkisar antara 6-12 petak per RTP. Ukuran petak yang digunakan bervariasi antara $5 \times 10$ $\mathrm{m}^{2} ; 5 \times 5 \mathrm{~m}^{2}$; dan $5 \times 7 \mathrm{~m}^{2}$. Jenis ikan yang dipelihara adalah ikan mas dan nila. Lokasi budi daya ikan tersebar di beberapa perairan seperti Illuta dan Tabumela.

Keramba untuk keperluan budi daya dengan sistem ini terbuat dari kayu atau bambu dan kawat kasa. Keramba dipasang terapung dengan jalan menggantungkan pada tiang bambo yang dipancangkan pada dasar perairan. Ikan yang dipelihara adalah ikan nila dan mas. Jumlah benih berkisar antara 7.000-20.000 ekor/petak tergantung dari ukuran luas keramba. Rata-rata padat tebar antara 280-800 ekor benih/m² dengan ukuran benih ikan 3-4 cm/ekor. Pemeliharaan dilakukan selama empat bulan. Pakan yang diberikan berupa pelet dan dedak jagung. Bobot panenan ikan berkisar antara 125-200 g/ekor.

\section{Aspek Sosial Ekonomi}

Mata pencaharian masyarakat pesisir danau cukup beragam, antara lain petani, pedagang, pengrajin, PNS, tukang, karyawan, nelayan, dan buruh. Persentase terbesar didominansi oleh masyarakat petani dan nelayan, di mana masingmasing mencapai 46,1 dan 16,7\%.

Jumlah nelayan di Danau Limboto mencapai 1.454 RTP yang tersebar hampir di selingkar danau, khususnya di Desa Payunga, Iluta, Lemehe Timur, Bua, Hungaluwa, Barakati, dan Dembe. Di desadesa tersebut jumlah rumah tangga yang bermata pencaharian sebagai nelayan mencapai 30-64\% dari total rumah tangga.

Nelayan di Danau Limboto merupakan nelayan yang berusia antara 14-51 tahun, komposisi terbesar adalah nelayan yang berusia antara 25-44 tahun (68,5\%). Hal ini menggambarkan bahwa usia nelayan termasuk usia produktif, yang berarti bahwa usia muda pada umumnya relatif lebih ekonomis dan aktif dalam mengadopsi ilmu pengetahuan dan teknologi.

Berdasarkan atas tingkat pendidikan, sebagian besar nelayan di Danau Limboto hanya berpendidikan setingkat SD $(61,5 \%)$. Sisanya yaitu 30,8\% memiliki pendidikan setingkat SLTP dan SLTA, dan 7,7\% nelayan yang tidak mengikuti pendidikan formal.

Pendapatan usaha penangkapan ikan di Danau Limboto berkisar antara Rp.10.000180.000,-/RTP/hari. Pendapatan nelayan 
tersebut sangat dipengaruhi oleh jumlah alat tangkap yang dimiliki. Investasi yang diperlukan dalam kegiatan usaha yang dikeluarkan nelayan berkisar antara Rp.500.000-Rp.1.400.000,-.

Kelayakan usaha penangkapan menunjukan bahwa pada beberapa jenis alat tangkap, usaha penangkapan ikan cukup menguntungkan dan layak untuk diusahakan, dengan tingkat kelayakan usaha bervariasi antara 2,3-21,6 (Tabel 8).

Saat ini jumlah pembudidaya ikan dalam keramba 379 RTP yang terdiri atas pembudidaya ikan keramba (29 RTP), dan pembudidaya ikan jaring apung (350 RTP).
Pada perikanan budi daya, hampir seluruh ikan hasil budi daya dijual di lokasi budi daya. Pembeli mendatangi lokasi budi daya secara periodik dan membeli hasil budi daya secara bertahap. Tingkat harga jual di lokasi untuk jenis ikan nila dapat mencapai Rp.12.000/kg, dengan tingkat harga tersebut maka pembudidaya dapat memperoleh keuntungan usaha rata-rata Rp.14.278 juta/petak/ musim. Dari hasil perhitungan di atas, dapat diketahui bahwa nilai B/C mencapai 2,1 artinya bahwa untuk setiap rupiah yang dikeluarkan akan memberikan kontribusi keuntungan Rp.2,1. Kegiatan budi daya sistem keramba tancap di Danau Limboto cukup menguntungkan dan layak untuk diusahakan.

Tabel 8. Kelayakan usaha pada beberapa jenis alat tangkap di Danau Limboto Table 8. Feasibility study on several types of fishing gear in Lake Limboto

\begin{tabular}{|c|c|c|c|c|c|c|}
\hline $\begin{array}{c}\text { Jenis alat } \\
\text { tangkapl } \\
\text { Types of } \\
\text { fishing } \\
\text { gear }\end{array}$ & $\begin{array}{c}\text { Kepemilikan } \\
\text { alat tangkap/ } \\
\text { Ownership } \\
\text { fishing } \\
\text { gear } \\
\text { (unit/RTP) }\end{array}$ & $\begin{array}{c}\text { Hasil } \\
\text { tangkapan/ } \\
\text { Haul } \\
\text { (kg/trip)/ } \\
\text { (kg/musim) }\end{array}$ & $\begin{array}{l}\text { Jenis ikan } \\
\text { tangkapan/ } \\
\text { Type of fish } \\
\text { catches }\end{array}$ & Pendap & $\begin{array}{l}\text { atan/Income } \\
\text { Rp/bulan*) } \\
\text { dan atau } \\
\text { (Rp/musim) }\end{array}$ & $\begin{array}{c}\text { Kelayakan } \\
\text { usahal } \\
\text { Feasibility } \\
\text { study } \\
\text { (R/C ratio) }\end{array}$ \\
\hline $\begin{array}{l}\text { Pajala } \\
\text { /Gillnet }\end{array}$ & 3 & 4,8 & $\begin{array}{l}\text { Mujair, nila, } \\
\text { manggabai, } \\
\text { tawes, sepat, } \\
\text { payangga, } \\
\text { gabus }\end{array}$ & 25.376 & 761.265 & 3,9 \\
\hline Dudayaho & 1 & 30,0 & Hulu'u & 25.509 & 765.292 & 2,4 \\
\hline $\begin{array}{l}\text { Jaring } \\
\text { tancap }\end{array}$ & 1 & 6,0 & $\begin{array}{l}\text { Nila, } \\
\text { manggabai }\end{array}$ & 35.175 & 1.055 .250 & 3,0 \\
\hline Bunggo & 200 & 7,0 & $\begin{array}{l}\text { Sogili, } \\
\text { mangagbai, } \\
\text { payangka }\end{array}$ & 186.356 & 5.590 .679 & 21,6 \\
\hline $\begin{array}{l}\text { Bibilo } \\
\left(200 \mathrm{~m}^{2}\right)\end{array}$ & 3 & 600 & $\begin{array}{l}\text { Nila, mujair, } \\
\text { gabus, } \\
\text { tawes }\end{array}$ & 42.476 & 7.645 .689 & 11,3 \\
\hline
\end{tabular}

\section{PENGELOLAAN PERIKANAN}

Berdasarkan atas uraian sebelumnya maka langkah-langkah pengelolaan perikanan yang perlu dilakukan meliputi:
1. Rehabilitasi habitat danau

Rehabilitasi habitat danau perlu dilakukan terutama dengan cara mengendalikan gulma air eceng gondok. 
Beberapa cara pengendalian yang dapat dilakukan sebagai berikut:

a. Pengendalian gulma air eceng gondok menggunakan cara campuran antara fisik dan biologis. Ikan koan dipelihara dalam kolam pagar atau hampang (pen culture) menggunakan pakan eceng gondok. Apabila dapat dikembangkan sekitar 1.000 unit hampang dengan pakan $100 \mathrm{~kg}$ eceng gondok per hari dan lama pemeliharaan empat bulan maka jumlah eceng gondok yang dapat dimanfaatkan $120.000 \mathrm{~kg} x$ $1.000=120.000$ ton atau setara dengan 120 ha luasan eceng gondok yang menutupi permukaan air danau.

b. Pengendalian dengan cara pengurangan jumlah kepemilikan bibilo. Jumlah pemilik bibilo di Danau Limboto 750 RTP. Rata-rata kepemilikan tiap nelayan tiga bibilo. Luas rata-rata setiap bibilo 400 $\mathrm{m}^{2}$. Untuk mengurangi gulma, maka kepemilikan diubah menjadi kelompok (minimum tiga orang per bibilo) sehingga terjadi pengurangan bibilo 500 unit bibilo atau setara dengan pengurangan gulma sekitar 20 ha.

c. Pengendalian secara fisik. Pada saat air surut selama enam bulan satu orang nelayan diwajibkan untuk mengangkat seluas satu meter persegi eceng gondok setiap hari. Jika hal ini dilakukan maka 1.500 orang $\times 180$ hari $\times 1 \mathrm{~m}^{2}$ luas eceng gondok sama dengan $270.000 \mathrm{~m}^{2}$ atau 27 ha luas eceng gondok dapat diangkat ke luar perairan.

Dengan demikian dari ketiga cara pengendalian tersebut dalam satu tahun permukaan eceng gondok dapat dikurangi seluas 167 ha. Hal ini akan meningkatkan produksi primer perairan yang terbuka $1.670 .000 \mathrm{~m}^{2} \times 2 \mathrm{~m} \times 16,9 \mathrm{mg}=56.446$ ton/tahun.

\section{Penentuan tata ruang usaha perikanan}

Berdasarkan atas analisis kesesuaian kondisi biolimnologi yang dikaitkan dengan penataan ruang perairan dan meminimalisir kemungkinan terjadinya kemungkinan konflik pemanfaatan ruang maka perlu dilakukan klasifikasi berdasarkan atas karakteristik lokasi dan analisis keruangan khususnya menata sektor perikanan di Danau Limboto.

Hasil analisis spasial terhadap kesesuaian ruang di Danau Limboto dapat dikelompokan dalam dua jenis pemanfaatan yaitu:

a. Kawasan inti. Kawasan ini diperuntukan sebagai kawasan perlindungan sumber daya ikan atau suaka perikanan. Berdasarkan atas kriteria kesesuaian untuk daerah suaka perikanan tersebut maka dapat diidentifikasi beberapa lokasi yang memenuhi syarat sebagai daerah calon suaka perikanan di Danau Limboto antara lain perairan sekitar Dembe, perairan teluk daerah Hunggaluwa dan perairan teluk daerah Payunga. Dari ketiga lokasi tersebut perairan Dembe merupakan perairan yang paling memenuhi syarat sebagai calon suaka perikanan dengan parameter pendukung antara lain fluktuasi tinggi muka air, kondisi biolimnologi, vegetasi alami dan landuse, serta integritas ekologi.

b. Kawasan pemanfaatan. Kawasan ini dapat digunakan untuk budi daya ikan, perikanan tangkap, dan pemanfaatan lain.

1. Kawasan budi daya: Selain kondisi biolimnologi yang sesuai dengan baku mutu untuk perikanan, beberapa persyaratan daerah budi daya di perairan danau antara lain 
merupakan perairan yang sifatnya luas, tergenang sepanjang tahun dengan aksesibilitas yang cukup mudah. Hasil identifikasi menunjukan bahwa lokasi yang sesuai untuk budi daya berada di perairan sekitar lluta. Namun yang perlu diperhatikan dalam kegiatan budi daya adalah pembatasan jumlah keramba sesuai dengan daya dukung perairan setara dengan 1.000 unit keramba.

2. Kawasan penangkapan: Meliputi seluruh perairan danau kecuali daerah yang dilindungi sebagai kawasan suaka perikanan dan kawasan yang telah ditetapkan untuk budi daya, dan jalur transportasi atau pelayaran.

3. Kawasan pemanfaatan lain: Merupakan kawasan di mana berbagai aktivitas pemanfaatan dapat dilakukan dengan tetap memperhatikan kaidah-kaidah kelestarian sumber daya perikanan seperti pengembangan wisata dan usaha pertanian pasang surut.

3. Revitalisasi Peraturan Daerah Kabupaten Gorontalo Nomor 67 Tahun 2000.

Isi peraturan daerah tersebut diatas antara lain melarang penggunaan alat tangkap yang merusak, seperti stroom dan Dudayaho. Bila peraturan daerah tersebut efektif diterapkan, maka akan menghasilkan peningkatan produksi ikan dan konservasi sumber daya ikan asli (ikan payangga dan manggabae). Ikan payangga yang tertangkap di Danau Limboto memiliki kisaran ukuran panjang 5,2-18,2 cm dan bobot 3,1-63,1 g sedangkan ukuran panjang ikan manggabai 4,9-28,5 cm dan bobot 0,9$178,1 \mathrm{~g}$. Alat tangkap yang digunakan untuk menangkap kedua jenis ikan tersebut di antaranya jaring insang (gillnet), dudayaho, dan bunggo (trap). Ukuran ikan yang tertangkap dengan alat tangkap dudayaho berukuran 1,5-5,0 cm (3-5 g). Alat tangkap dudayaho dapat menangkap 10.000-20.000 ekor/hari, sedangkan alat tangkap dudayaho yang beroperasi di Danau Limboto sekitar $10-15$ buah alat dudayaho, jadi sehari tertangkap sekitar 200.000 ekor $\times 4 \mathrm{~g}=$ $800.000 \mathrm{~g}$ atau $800 \mathrm{~kg}$ ikan, dengan harga ikan Rp.10.000,-/kg akan dihasilkan nilai produksi Rp.8.000.000. Apabila alat dudayaho dan stroom dapat dihilangkan maka ikan payangga dan manggabae dapat tumbuh membesar sampai ukuran sekitar 50 dan $100 \mathrm{~g}$ (rata-rata $75 \mathrm{~g}$ ). Dengan kelulusan hidup sekitar $60 \%$, maka hasil tangkapan $800 \mathrm{~kg} / \mathrm{hari}$ di atas akan menjadi 200.000 ekor $\times 60 \% \times 75 \mathrm{~g}=90.000 \mathrm{~kg}$. Dengan harga ikan yang sama Rp.10.000,$/ \mathrm{kg}$ maka akan dihasilkan nilai produksi Rp.90.000.000,-. Dengan demikian, upaya pengendalian ini akan dapat meningkatkan produksi ikan dan pendapatan nelayan sekitar 10 kali lipat dan sekaligus melestarikan sumber daya ikan.

4. Revitalisasi kelembagaan nelayan dan pembudidaya ikan

Pengelolaan perairan umum daratan termasuk danau akan efektif bila melibatkan peran serta masyarakat yang tergabung dalam unit kelompok pengelola perikanan. Dalam hal ini peran kelompok pembudidaya dan nelayan dalam mengelola perikanan akan lebih menonjol. Pengembangan rezim pengelolaan perikanan secara bersama (fisheries comanagement) akan lebih sesuai untuk diterapkan. Untuk itu kelompok-kelompok yang sudah ada perlu diaktifkan dan ditingkatkan peran sertanya. Hal ini dimaksudkan untuk menjaga keberlanjutan usaha, produksi hasil tangkapan dan budi daya ikan serta kelestarian sumber daya ikan. Kelompok juga dapat berperan dalam menetapkan harga ikan sehingga tidak tergantung pada tengkulak. 


\section{KESIMPULAN DAN REKOMENDASI}

Danau Limboto sudah termasuk danau kritis akibat masalah sedimentasi dan eutrofikasi sehingga memerlukan langkahlangkah penyelamatan baik secara fisik maupun biologis. Untuk menjamin kelestarian sumber daya ikan dan perairan Danau Limboto diperlukan langkah-langkah sebagai berikut:

1. Penetapan tata ruang pemanfaatan sumber daya perairan danau.

2. Pengendalian eceng gondok secara fisik dan biologis (menggunakan ikan koan dengan sistem budi daya dalam keramba jaring apung).

3. Revitalisasi Peraturan Daerah Kabupaten Gorontalo Nomor 67 Tahun 2000 tentang kelembagaan kelompok pembudidaya ikan dan nelayan.

\section{DAFTAR PUSTAKA}

Anonimus. 2006. Ringkasan eksekutif. Kajian Ekohidrologi sebagai Dasar Penetapan Pengelolaan Danau Limboto secara Terpadu. Pusat Penelitian Limnologi. Lembaga Ilmu Pengetahuan Indonesia Bekerjasama dengan SKNVT. PBPP Gorontalo. 74 pp.

Anonimus. 1991. Danau Limboto. Masalah Pengembangan dan Pemanfaatannya. Daerah Tingkat II, Kabupaten Gorontalo, Sulawesi Utara. 28 pp.

Badan Perencanaan Pembangunan Nasional. 2003. Strategi dan rencana aksi keanekaragaman hayati Indonesia 2003-2020. Dokumen Nasional. 150 pp.

Center, T. D., T. K. Van, A. F. Dray, S. J. Franks, M. T. Rabelo, P. D. Pratt, \& M.
B. Rayamajhi. 2005. Herbivory alters competitive interactions between two invasive aquatic plants. Biological Control. 33: 173-185.

Djaenudin. 2006. Pengolahan air limbah domestik menggunakan tumbuhan eceng gondok dalam sistem lahan basah buatan dengan aliran umpan kontinu. Indonesia Symposium on Science and Technology. Pusat Penelitian Kimia. Lembaga Ilmu Pengetahuan Indonesia.

Eccles, D. H. 1992. Species identification sheets for fishery porpuses. Field Guide to the Freshwater Fishes of Tanzania. FAO. Rome. VI+145 pp.

Haryatun. 2008. Teknik identifikasi jenis gulma dominan dan status ketersediaan hara nitrogen, fosfor dan kalium beberapa jenis gulma di lahan rawa Lebak. Buletin Teknik Pertanian. 13 (1): 19-21.

Hasim. 2007. Eceng Gondok Pembersih Polutan Logam Bobot. Dosen Biokimia dan Toxikologi. Fakultas Matematika dan Ilmu Pengetahuan Alam. Pascasarjana. Institut Pertanian Bogor.

Hulinggi, S. M. 2005. Analisis vegetasi tumbuhan air di perairan Danau Limboto, Kabupaten Gorontalo. Skripsi. Universitas Negeri Gorontalo. 47 pp.

Ismail, G. 2006. Masterplan penyelamatan Danau Limboto. Pemerintahan Provinsi Gorontalo dalam Seminar Penyelamatan Danau Limboto. Jakarta. Tanggal 21 April 2006.

Kementerian Lingkungan Hidup. 2006. Pengelolaan Kualitas Air dan Pengendalian Kerusakan Danau. 
Kementrian Lingkungan Hidup. 2003. Status Lingkungan Hidup Indonesia 2002. Kementrian Lingkungan Hidup. Jakarta. $151 \mathrm{pp}$.

Krismono, L. P. Astuti, \& Y. Sugiyanti. 2009. Karakteristik kualitas air Danau Limboto, Provinsi Gorontalo. Jurnal Penelitian Perikanan Indonesia. 15 (1): 59-68.

Krismono, A. Suryandari, A. Nurfiarini, N. Widarmanto, Mujiyanto, L. P. Astuti, \& Y. Sugianti. 2007. Rehabilitasi dan konservasi sumber daya perikanan Danau Limboto. Laporan Akhir. Loka Riset Pemacuan Stok Ikan (Tidak Dipublikasikan).

Lamangantjo, C. J. 1991. Bibilo dan pengaruhnya terhadap ekosistem perairan Danau Limboto. Skripsi. Universitas Negeri Gorontalo. 79 pp.

Marson. 2006. Jenis dan peranan tumbuhan air bagi perikanan di perairan Lebak Lebung. BAWAL Widya Riset Perikanan Tangkap. Pusat Riset Perikanan Tangkap. 1 (2): 49-52.

Nurminem, L. 2003. Macrophyte species competition reflecting water quality changes in adjacent water bodies of lake Hindiidenvesi, S. W. Finland. Ann.Bot.Fennici. 40: 199-208.

Odum, E. P. 1998. Dasar-Dasar Ekologi. Alih Bahasa Samingan. T. Edisi Ketiga. Universitas Gadjah Mada Press. Yogyakarta.

Penfaund, W. T. \& T. T. Early. 1948. The biology of the water hyacinth. Ecologycal Monographs. 18: 447-472.

Petr, T. 2000. Interaction between fish and aquatic macrophytes in inland waters a review. FAO Fisheries Technical Paper. No.396. Rome. 185 pp.

Pipalova, I. 2006. A review of grass carp use for aquatic weed control and its impact on water bodies. J. Aquat. Plant. Manage. 44: 1-12.

Pokorny, J. \& J. Kvet. 2004. Aquatic plant and lake ecosystems in the lakes. Handbook. Vol.1 Limnology and Limnetic Ecology. ed. By O'Sullivan, P. E. \& C. S. Reynolds. Blackwell Publishing. 309340.

Rahmi, A. 1999. Pengaruh waktu pemberian eceng gondok dan urea tablet terhadap kandungan $\mathrm{N}$ tanah, kandungan $\mathrm{N}$ tanaman, dan hasil padi gogo (Oryza sativa L.). Pada Ultisols sebagai Bekas Ditumbuhi Alang-Alang. Fakultas Pertanian. Universitas Mulawarman. Samarinda. 12 pp. (Tidak Dipublikasi).

Sarnita, A. S. 1994. Kajian tentang sumber daya perikanan Danau Limboto, Sulawesi Utara. Prosiding Seminar Perikanan Air Tawar. Balai Penelitian Perikanan Air Tawar. 53-66.

Soerjani, M. 1982. Masalah gulma di Indonesia. Prosiding No.1. Seminar Perikanan Perairan Umum. Badan Penelitian dan Pengembangan Pertanian. 33-41.

Soerjani, M. 1981. Dampak eutrofikasi perairan terhadap gulma air. Seminar Terbatas Pengaruh Penggunaan Pupuk dan Pestisida terhadap Lingkungan. Lembaga Ekologi. Universitas Padjajaran. Bandung.

Soerjani, M., C. Parker, S. Tjitrosemito, G. E. Allen, C. K. Varshney, D. S. Mitchell, \& J. V. Pancho. 1976. Aquatic weed. 
Proceeding of Southwest Asian Workshop on Aquatic Weed. Biotrop Special Publ. 1: 45 pp.

Steenis, C. G. G. J. van, \& F. Ruttner. 1933. Die Pteridophyten and Phanerogamen der Deutschen Limnologischen Sunda Expedition. Archiv. Fur Hydrobiologie. Sup. BandXI. Tropische Cinnengewasser Band III. E. Scheiwerbartsche Verlagbuch handlung. Stuttgart.

Vass, K. P. \& J. J. Schuurman. 1949. On the Ecology and Fisheries of Some Javanese Freshwater, Mededeling van het algemeen Proefstation Voor de Landbouw. No. 97.

Vaas, K. P. 1956. Ekologi dan Perikanan dari Rawa Aopa (Sulawesi Tenggara) Indonesia. Lembaga Penelitian Perikanan Darat. Laporan. No.8.

Wahyono, M. H., M. Nasoetion, I. Mangasih, \& S. Sumarsih. 2006. Kandungan Asam Amino dan Kecernaan Nutrien Eceng Gondok Terfermentasi Aspergillus niger pada Itik Tegal.
Lembaga Penelitian. Fakultas Peternakan. Universitas Padjajaran.

Warsa, A., Krismono, \& L. P. Astuti. 2008. Evaluasi kesesuaian habitat grass carp (Ctenopharyngodon idella) untuk pengendalian eceng gondok (Eicchornia crassipes) di Danau Limboto. Prosiding Seminar Nasional Limnologi IV. Pusat Penelitian Limnologi. Lembaga IImu Pengetahuan Indonesia. 92-102.

Warsa, A., Krismono, A. Nurfiarini, \& L.P. Astuti. 2008. Danau Limboto: Kepentingan ekonomi nelayan VS kelestarian lingkungan. Prosiding Seminar Nasional Tahunan V Hasil Penelitian Perikanan dan Kelautan. Universitas Gadjah Mada dan Badan Riset Kelautan dan Perikanan. 12: 1-6.

Wetzel, R. G. 2001. Limnology Lake and River Ecosystem Third Edition. Academic Press. California.

Whitten, A. J., M. Mustafa, \& G. S. Henersen. 1987. Ekologi Sulawesi. Gadjah Mada University Press. Yogyakarta. 